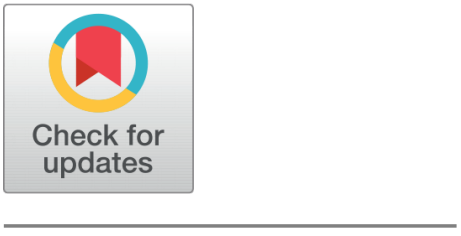

OPEn ACCESS

Received: 09.02.2021

Accepted: 21.03 .2021

Published: 03.05 .2021

Citation: Dina S, Thankamani VT, Emilia Abraham T (2021) A novel cellulolytic system from Aspergillus flavipes for lignocellulosic bio-conversion. Indian Journal of Science and Technology 14(15): 1219-1232. https://doi.org/ 10.17485/IJST/v14i15.209

* Corresponding author.

Tel: 9845693891

drsdina@yahoo.co.in

Funding: CSIR research grant

Competing Interests: None

Copyright: ๑ 2021 Dina et al. This is an open access article distributed under the terms of the Creative Commons Attribution License, which permits unrestricted use, distribution, and reproduction in any medium, provided the original author and source are credited.

Published By Indian Society for Education and Environment (iSee)

ISSN

Print: 0974-6846

Electronic: 0974-5645

\section{A novel cellulolytic system from Aspergillus flavipes for lignocellulosic bio-conversion}

\author{
S Dina ${ }^{1 *}$, V T Thankamani ${ }^{2}$, T Emilia Abraham ${ }^{3}$ \\ 1 Scientific Research Solution Private Limited, Karnataka, India. Tel.: 9845693891 \\ 2 Professor and Head (Retd), Department of Biotechnology, University of Kerala, \\ Thiruvananthapuram, India \\ 3 Scientist G (Retd), National Institute for Interdisciplinary Science and Technology (CSIR), \\ Thiruvanathapuram, 695019, India
}

\section{Abstract}

Background/Objectives: The importance of enzymatic bioconversion of cellulose cannot be understated and enzyme systems which complement existing enzymes, with broad ranges of $\mathrm{pH}$ and temperatures and hydrolyze cellulose synergistically with other enzymes are required for bioconversions. The study was undertaken to isolate and characterize cellulolytic organisms. Methodology: Isolation of cellulolytic strains from soil samples with degrading cellulosic wastes, screening and species level identification of Fungal strain was conducted. Stability of the enzyme systems over different $\mathrm{pH}$ and temperature and purification study of enzymes were carried out. Results: Fungal isolate, which exhibited 0.08 IU of filter paper (FP) activity, 0.33 IU of Carboxy methyl cellulose (CMC) activity and $15 \mathrm{IU}$ of xylanase activity was selected and identified as Aspergillus flavipes. Purification by ion exchange chromatography and gel filtration chromatography yielded a typical endoglucanase, a fraction showing activity with both avicel and caboxy mthyl cellulase(CMC) and a third fraction against CMC and avicel. GPC of third fraction showed that the enzymes had cross reactivity to the substrates used. Conclusion: Our study proved that Aspergillus flavipes is capable of degrading lignocellulose and its FP activity and CMC activity was higher than other isolates and was comparable to enzymes of a standard strain $T$. koninjii. To our knowledge this study is the first detailed report of a system of cellulases, suitable for saccharification of lignocellulosic biomass alone or synergistically with other enzymes produced by Aspergillus flavipes.

Keywords: Filter paper activity; CMC; glucosidase; endoglucanase; pNPG; lignocellulosic $\beta$ saccharification

\section{Introduction}

Cellulose, the most predominant organic polymer on earth, is a polysaccharide carbohydrate which is continually replenished by photosynthetic reduction of carbon dioxide that is catalyzed by sunlight. The process of degradation of cellulose to glucose 
is the key factor responsible for utilizing cellulosic wastes. The cellulosic wastes, such as municipal waste, agricultural wastes and animal manure act as feedstock for production of chemicals, food and energy. Cellulases make up around $75 \%$ of the total enzymes required in biorefineries, pulp and paper, textile and food/feed industries ${ }^{(1)}$. The hydrolysis of cellulose using enzymes are very specific and do not produce undesirable by-products ${ }^{(2)}$. The amalgamation of different enzymes is an essential factor for the efficient degradation of cellulose. The mechanism of synergism or amalgamation needs to be studied as it would be instrumental in designing efficient enzyme mixtures for cellulose degradation ${ }^{(3)}$. The first step towards understanding the mode of action is purification of different components of the enzyme complex. Ion-exchange chromatography is the widely accepted method of cellulase purification, as it has high resolving power, high capacity, simple operational mode, and is highly robust, generic and economical in addition ${ }^{(4)}$.

Recent years have seen a surge of interest in production of fuel from biomass using cellulases. Since there is decreased availability of fossil fuels, it has affected the fermentable sugars production. The producers of fermentable sugars are transitioning towards renewable resources creating a greater demand for cellulases in lignocellulose-based biorefinery ${ }^{(5)}$ thereby fueling a need for cost effective enzyme production. Thus, there is a high requirement for the development of an efficient bioconversion process, which could reduce the cost of enzyme production. Extensive research for obtaining better yields and novel solutions for bioconversion is being carried out ${ }^{(6)}$.

In the current study, Fungi strains were isolated from soil samples and were screened for presence of cellulolytic potential. An isolate with the highest activity was identified and used for purification of the enzyme complex responsible for cellulose degradation in this strain. This fungus was shown to be capable of using natural substrates for the production of cellulase in high amounts cost effectively by using lignocellulosic bio wastes for energy. Hence, it could be the answer to the quest for efficient and economical cellulase producers.

\section{Materials and Methods}

Surface soil samples were taken from the campus of National Institute for Interdisciplinary Science and Technology (NIIST) Trivandrum during winter season. Czapek-Dox broth, Sabouraud Dextrose Agar (SDA), Potato Surose Agar (PSA), Oat spelt xylan, xylose, Lactophenol Cotton Blue (LCB) blue dextran lactose, urea, Malt Extract Agar (MEA), from Sigma, citrate buffer, Congo red stain, Dinitrosalicylic acid (DNS), p-nitro phenyl- $\beta$-D-glucopyranoside (pNPG), Whatman No.1 Filter paper (Millipore) Erlenmeyer flasks (Borosil). Rice bran, saw dust, rice straw, wheat bran, bagasse, coir pith and green gram hull were purchased locally. The pure cellulose used was microcrystalline cellulose from Lobo, CMC (Aldrich, UK). Opti-phot-2 microscope (Nikon), Tangential flow pellicon cassete, ultra-filtration system with polysulphone membranes with a 10,000 dalton cut off, dialysis membrane(from Millipore), Biogel P 100, glass column of dimensions 10 x $2.5 \mathrm{~cm}$ from Bio-Rad, Pharmacia LKB peristaltic pump, Redifrac fraction collector, glass column, DEAE Sephadex A 50 (Pharmacia; dimension $70 \mathrm{x} 2.5 \mathrm{~cm}$ ), spectrophotometer (UV 2001 Shimadzu, Japan), Bovine serum albumin $(66,000)$, carbonic anhydrase $(29,000)$ and cytochrome C $(12,400)$, blue dextran (Sigma ; 25,00,000 Daltons), and other common laboratory reagents of analytical grade were used.

\subsection{Collection of soil samples}

Different samples of surface soil were collected from places where cotton, wood and paper wastes were dumped, and used for the isolation of cellulolytic microorganisms.

\subsection{Isolation of cellulolytic microorganisms}

Soil samples were serially diluted and cultured in minimal agar medium of Czapek-Dox with pH 5.5 at ambient temperature for 5-7 days. Nineteen strains were selected. The organisms were purified on SDA plates and single colonies were sub-cultured on to PSA slants. The purified isolates were inoculated in plates of minimal medium with $0.25 \%$ CMC and $1.5 \%$ agar ${ }^{(7)}$. The plates were incubated up to $48 \mathrm{~h}$ and stained with Congo red staining. Organisms exhibiting a pale degradative halo with orange edges were selected.

\subsection{Screening of isolates}

Eight fungal strains which showed significant degradation of filter paper as evident by the thinning of paper and bigger clearance zone in Congo red staining were selected for submerged fermentation studies to assess their potential in producing extra cellular cellulase. The $\mathrm{pH}$ of the medium was 4.5 to 5, screening was done by measuring CMCase activity, FP assay, cotton hydrolysis, temperature stability, enzyme production on native substrates and Xylanase activity. 


\subsection{Fermentation studies}

Submerged fermentation method using Czapek-Dox minimal medium with pH 5.5 along with $1 \%$ microcrystalline cellulose for carbon source and $0.2 \%$ peptone, was used to culture the fungi, Fermentation was carried out for 3 days at $110 \mathrm{rpm}$. The fungal biomass was separated by centrifugation at $6,000 \mathrm{xg}$. The supernatant extracted after centrifugation was used as a source of crude enzyme and the total protein concentration was estimated.

\subsubsection{Cellulase enzyme assays}

CMC solution $(0.5 \mathrm{ml} ; 2 \%)$ in citrate buffer $(0.05 \mathrm{M} ; \mathrm{pH} 4.8)$, and $0.5 \mathrm{ml}$ crude enzyme was incubated at $50^{\circ} \mathrm{C}$ for $30 \mathrm{~min}$. Filter paper assay was performed to determine the total cellulase activity. Whatman No.1 filter paper strip $(1.0 \times 6.0 \mathrm{~cm}, 50 \mathrm{mg})$ in $0.5 \mathrm{ml}$ citrate buffer and $0.5 \mathrm{ml}$ crude enzyme was incubated at $50^{\circ} \mathrm{C}$ for $1 \mathrm{~h}^{(8)}$. The FP activity was expressed as international units or FPU ${ }^{(9)}$. The assay of cotton hydrolysis was performed with $10 \mathrm{mg}$ cotton in $0.5 \mathrm{ml}$ citrate buffer of $0.05 \mathrm{M}$ and $0.5 \mathrm{ml}$ enzyme, incubated for $3 \mathrm{~h}$ at $50^{\circ} \mathrm{C}$. All the enzyme assays were terminated by adding DNS and the reducing sugar released was measured as absorbance at $540 \mathrm{~nm}$ in a UV-Visible spectrophotometer against appropriate blanks ${ }^{(10)}$.

\subsubsection{Enzyme production on native substrates}

The isolate $\mathrm{X} 1$ was grown on cellulosic substrates like microcrystalline cellulose, CMC, rice bran, sawdust, rice straw and wheat bran. Concentrations used was 2\%. Enzyme activity with CMC and FP were compared using culture filtrates of $233 \mathrm{~h}$.

\subsubsection{Xylanase activity}

The fermentation broth with straw as substrate from the previous experiment was used for xylanase assay. The substrate used was $0.5 \%$ of oat spelt xylan, dissolved in $0.2 \mathrm{M}$ phosphate buffer ( $\mathrm{pH} 7$ ) The reaction was terminated by adding $3 \mathrm{ml}$ DNS and boiling for exactly $5 \mathrm{~min}$ in a water bath. The color developed was measured as absorbance at $540 \mathrm{~nm}$ using spectrophotometer calibrated with standard xylose. Activity was expressed in International units.

\subsection{4 $\beta$-glucosidase activity}

The substrate used was $1 \mathrm{ml}$ of $5 \mathrm{mM}$ pNPG (Sigma, USA). The volume of enzyme used was $0.2 \mathrm{ml}$ and acetate buffer was $1.8 \mathrm{ml}(0.1 \mathrm{M}, \mathrm{pH} 4.8)$. Incubation was done for $30 \mathrm{~min}$ at $50 \pm 1^{\circ} \mathrm{C}$ temperature. The reaction was stopped using $4 \mathrm{ml}$ glycine $\mathrm{NaOH}$ buffer of $\mathrm{pH}$ 10.4. The amount of $\mathrm{pNPG}$ released was quantified. The absorbance was taken at $430 \mathrm{~nm}$ using UV spectrophotometer.

\subsection{Identification of the organism}

Slide cultures of the fungus were made for microscopic examination on sterile slides using sterile PDA blocks of sides $1 \mathrm{~cm}$ $\mathrm{x} 1 \mathrm{~cm}$ and $2 \mathrm{~mm}$ thick, inoculated and covered with coverslip. The coverslips were stained with Lactophenol cotton blue after 96 hrs, and photographed using Nicon-Opti-phot-2 microscope. The morphological structures were measured using compound microscope with different magnifications by micrometry. The fungus was identified using Smith's Introduction to Industrial Mycology ${ }^{(11)}$ and Compendium of Soil Fungi ${ }^{(12)}$.

\section{Purification}

Aspergillus flavipes was cultured in the submerged fermentation conditions. The culture filtrate was purified by using ion exchange chromatography followed by gel filtration of the major fraction of ion exchange to determine the molecular weight of cellulolytic enzyme components. After GPC, fractions were further subjected to native and SDS PAGE.

\subsection{Concentration of crude Enzyme}

Culture supernatants were obtained by centrifugation at 12,000g and concentrated, followed by protein precipitation and dialysis. The enzyme activity and total protein with filter paper as substrate was determined. The crude enzyme was concentrated using tangential flow Pellicon cassette ultrafiltration system with polysulphone membranes from Millipore with a 10,000 Dalton cut off and further subjected to ammonium sulphate precipitation up to $85 \%$ saturation. The precipitate obtained after centrifugation was dissolved in $10 \mathrm{mM}$ sodium acetate buffer (pH 4.9) dialysed against 200 times the volume of the same buffer. The total protein quantity as well as FP, endoglucanase and pNPG activity were determined. 


\subsection{Ion exchange chromatography}

Sephadex was packed in a glass column of dimensions $10 \times 2.5 \mathrm{~cm}$. The total bed volume was $49 \mathrm{ml}$, equilibrated with five bed volumes of $10 \mathrm{mM}$ sodium acetate ( $\mathrm{pH} 4.9$ ) buffer at a flow rate $35 \mathrm{ml} /$ hour using a Pharmacia LKB peristaltic pump. A linear gradient of 0-1 M NaCl was used to elute the bound enzymes. Fractions were collected using a Redifrac fraction collector. The absorption at $280 \mathrm{~nm}$ of all the fractions were taken to determine the amount of protein. Enzyme assays of 100 fractions were done using avicel, pNPG and CMC as substrates. The peak fraction from ion exchange, which showed all three enzyme activities, was subjected to gel permeation chromatography.

\subsection{Gel permeation chromatography}

Biogel P 100 in a glass column (dimension $70 \times 2.5 \mathrm{~cm}$ ) was used for GPC. The void volume was determined by using $4 \mathrm{~g}$ blue dextran $2 \mathrm{mg} / \mathrm{ml}$ (Sigma;). The fractions were collected by measuring the absorption at $280 \mathrm{~nm}$ using a spectrophotometer. The standards used were bovine serum albumin, carbonic anhydrase and cytochrome C, at a concentration of $2 \mathrm{mg} / \mathrm{ml}$ and total volume of $5 \mathrm{ml}$ each. For each of the proteins, the ratios of the elution volumes to the void volume was calculated. These ratios were plotted against molecular weights in a semi logarithmic graph. The major peak from ion exchange chromatography was loaded as the enzyme sample. The protein peaks were determined and the enzyme assay of all the fractions were assayed with the three substrates.

\subsection{Electrophoresis}

The peak fractions from GPC column were lyophilized and used for electrophoresis. The two fractions of GPC were subjected to electrophoresis under non denaturing conditions using acrylamide gels and denaturing conditions using SDS incorporated PAGE.

Native PAGE was performed in vertical slab gel system from Broviga. The sample was prepared by adding $1 \mathrm{M}$ Tris- $\mathrm{HCl}(\mathrm{pH}$ 6.8), $50 \%$ glycerol and $0.05 \%$ bromophenol blue. Wells were loaded with $40 \mu \mathrm{l}$ of prepared sample with $90 \mu \mathrm{g}$ protein. The gels were stained by silver staining method. Further SDS-PAGE (12\%) was done as per standard ptotocol

\section{Results}

\subsection{Isolation of strains}

Out of 35 grown colonies, 19 colonies randomly selected. Congo red screening method is used to detect colonies, with endo acting enzymes. The culture characteristics and the clearance zone diameter (in $\mathrm{mm}$ ) of these nineteen fungal isolates are described in Table 1.

Table 1. Morphological characters of fungal isolates

\begin{tabular}{lll}
\hline Isolate no & Clear zone $(\mathrm{mm})$ & $\begin{array}{l}\text { Description of colony (medium SDA) } \\
\text { X-1* }\end{array}$ \\
X-2* & 40 & $\begin{array}{l}\text { Yellowish, thin mycelia; aerial hyphae with brownish spores, older cultures showing a yellowish } \\
\text { brown liquid. }\end{array}$ \\
X-3* & 40 & $\begin{array}{l}\text { Creamy white, semitransparent colony both aerial and surface mycelia, green spores. } \\
\text { Central brown fluffy growth with white radiating hyphae, non-sporing. }\end{array}$ \\
$\mathrm{X}-4^{*}$ & 35 & White filamentous, long aerial hyphae, non-sporing \\
$\mathrm{X}-5^{*}$ & 35 & White filamentous hyphae with black spores \\
$\mathrm{X}-6^{*}$ & 25 & Slender white hyphae with black spores. \\
$\mathrm{X}-7^{*}$ & 24 & Creamy white hyphae with green spores \\
$\mathrm{X}-8^{*}$ & 23 & White hyphae, central white powdery spores \\
$\mathrm{X}-9$ & 20 & Pink powdery spots colony diameter $0.6 \mathrm{~cm}$ \\
$\mathrm{X}-10$ & 18 & White powdery spores, colony diameter $0.4 \mathrm{~cm}$ \\
$\mathrm{X}-11$ & 15 & Yellow non-sporing hyphae, highly branched \\
$\mathrm{X}-12$ & 15 & Creamy white and yellow hyphae with green spores \\
$\mathrm{X}-13$ & 13 & Pure white colonies 2 cm diameter, colonies highly wrinkled when viewed from underneath \\
$\mathrm{X}-14$ & 11 & Puffy green colonies, wrinkled under surface brownish pigment spreading the medium \\
$\mathrm{X}-15$ & 10 & Umbelliform colonies, central white hyphae, brown spores \\
$\mathrm{X}-16$ & 8 & Opaque, grey, thick, raised powdery colonies \\
$\mathrm{X}-17$ & 7 & Thin transparent white mycelia, yellow spores on aerial fluffy hyphae \\
\hline
\end{tabular}

Continued on next page 


\begin{tabular}{lcl}
\hline \multicolumn{2}{c}{ Table } & continued \\
\hline $\mathrm{X}-18$ & 7 & White transparent, margin fringed and thick. Black spores produced. \\
$\mathrm{X}-19$ & 4 & White opaque colonies, non -sporing \\
\hline
\end{tabular}

Colonies which exhibited higher growth as well as higher degrading capacity on FP as well as bigger zones of clearance on congo red stained CMC plates, were selected. The degradation of filter paper indicates the presence of a total cellulase activity as filter paper contains both crystalline and amorphous regions and its degradation requires the involvement of both endo/exo cellulase and cellobiohydrolase.

\subsection{Screening of isolates}

Eight fungi showing comparatively bigger zones of clearance in congo red pate method, were selected for submerged fermentation studies. The enzyme assay results proved that these comprised of both extracellular cellobiohydrolase and endoglucanase. Results are tabulated in Table 2. Isolate X1 showed maximum enzyme activity of 0.30 and $0.06 \mathrm{IU} / \mathrm{ml}$ on CMC and FP respectively.

Table 2. Comparison of the enzyme activities and total soluble protein content of eight fungal strains

\begin{tabular}{llll}
\hline \multirow{2}{*}{ Isolate } & \multirow{2}{*}{ Protein $(\mathrm{g} / \mathrm{ml})$} & Enzyme activity $\mathrm{IU} / \mathrm{ml}$ & \\
\cline { 3 - 4 } & & CMCase & FPase \\
\hline $\mathrm{X} 1$ & 1433 & 0.3 & 0.06 \\
$\mathrm{X} 2$ & 1582 & 0.23 & 0.08 \\
$\mathrm{X} 3$ & 850 & 0.08 & 0.035 \\
$\mathrm{X} 4$ & 700 & 0.06 & 0.02 \\
$\mathrm{X} 5$ & 790 & 0.05 & 0.01 \\
$\mathrm{X} 6$ & 800 & 0.04 & 0.018 \\
$\mathrm{X} 7$ & 893 & 0.022 & 0.011 \\
$\mathrm{X} 8$ & 1050 & 0.02 & 0.02 \\
\hline
\end{tabular}

\subsection{Cellulase assay}

The first four fungi were found to be more potent and their enzyme activities were compared with the extra cellular enzymes secreted by the standard strain T. koninjii under similar growth conditions as the new isolates. The Figure 1 A and B show the CMCase and FPU activity of different isolates measured at different culture times.

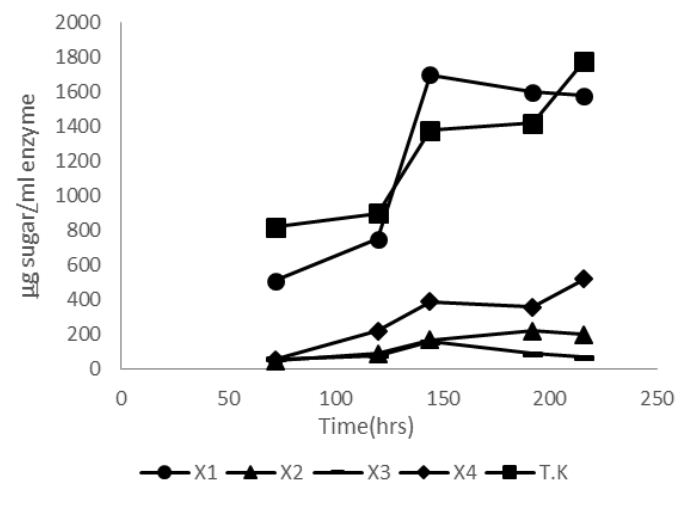

A

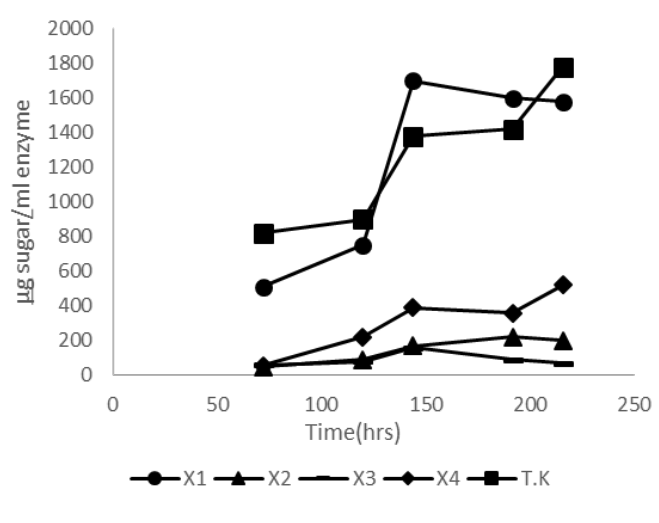

B

Fig 1. CMCase and FPase activity respectively of different isolates at different culture time

X1 showed 0.33 units of endoglucanase activity at $144 \mathrm{hrs}$. (measured as $1760 \mu \mathrm{g}$ sugar produced/ml enzyme) was better than the T.koninji which was $174 \mu \mathrm{g} / \mathrm{ml}$ at $216 \mathrm{hrs}$. However, FP activity peak was observed for both X1 and T. koninjii at 216 hrs and FP activity of X1 was 95\% of that produced by T. koninjii. Significant amounts of extracellular enzymes produced at early fermentation hours as compared to that in T. koninjii. indicated better productivity of the organism. Culture filtrates of 
X1 and T. koninjii exhibited cotton hydrolysing activity. The comparison of cotton hydrolysis of the isolates against T. koninjii cultured under same conditions is presented in Table 3.

Table 3. Hydrolysis of cotton

\begin{tabular}{ll}
\hline Strains & $\mu \mathrm{mol}$ glucose $/ \mathrm{ml} / \mathrm{hr}$ \\
\hline${ }^{\star}$ Trichoderma koningi & 20 \\
${ }^{\star}$ Fusarium solani & 11 \\
${ }^{\star}$ Trichoderma viride & 10 \\
${ }^{\star}$ Sporotrichum pulverulentum & 12 \\
$\mathrm{X} 1$ & 0.96 \\
$\mathrm{X} 2$ & 0.2 \\
$\mathrm{X} 3$ & 0.19 \\
T. koningi & 1 \\
\hline
\end{tabular}

\subsection{Xylanase activity}

The xylanase activity of the strain was 15 IU. Isolate X1 produced significant amounts of Xylanase in untreated rice straw, which indicates its efficiency in degradation of agricultural residues and other lignocellulosics.

\subsection{Enzyme activity with native cellulose}

The various carbon sources $\mathrm{C} 1$ to $\mathrm{C} 6$ were microcrystalline cellulose, CMC, rice bran, saw dust, rice straw and wheat bran respectively. The comparison of pure substrates with lignocellulosics were made. The cellulose content of lignocellulose is about $50 \%$ that of pure cellulose i.e. FPU/g substrate is highest for straw (Figure 2). Among all the native substrates, Rice straw resulted in the highest FPase activity of 0.25 unit. CMC activity with Rice straw as a substrate was 0.09 units).

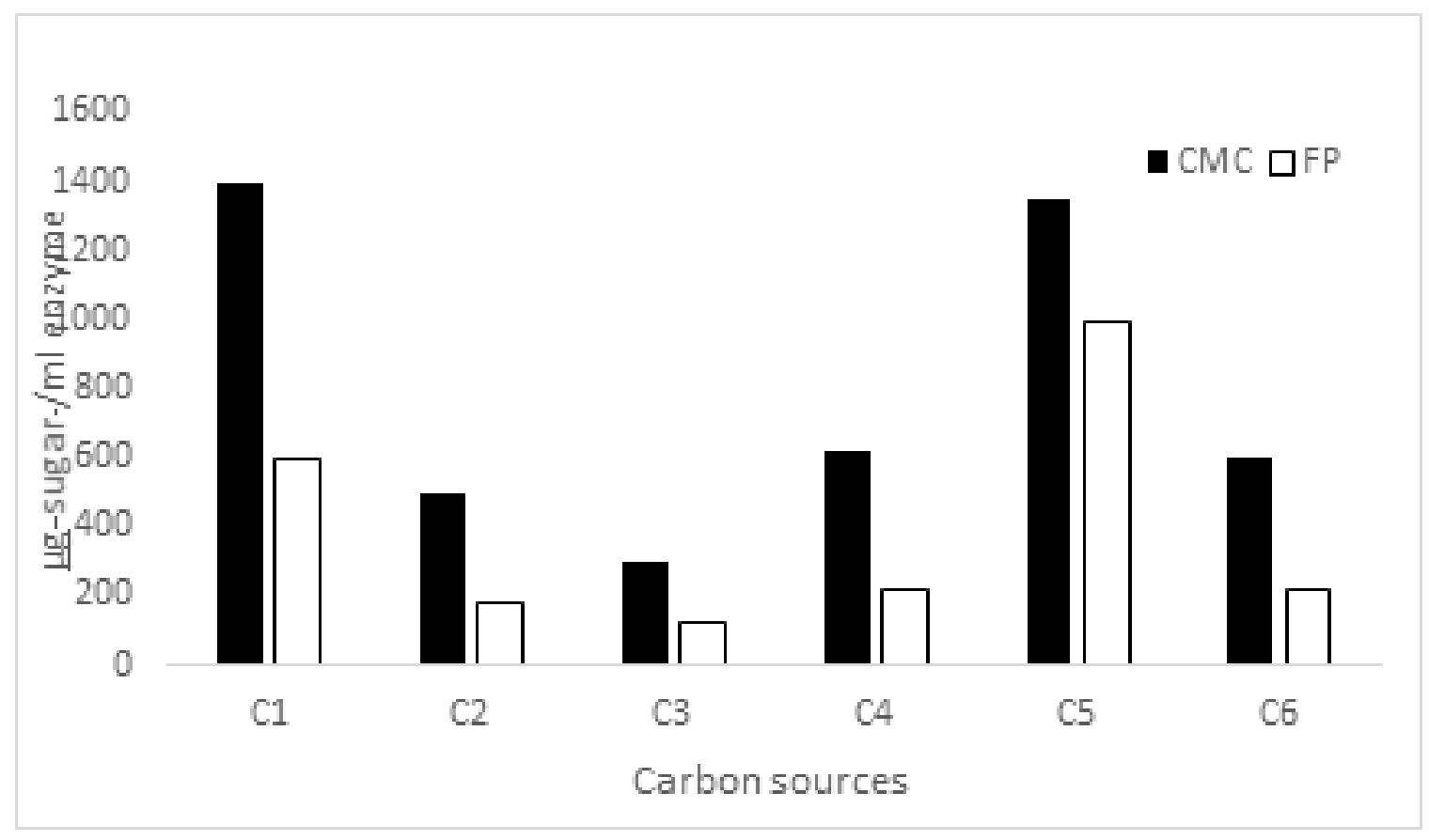

Fig 2. Enzyme activity with different cellulosic substrates 


\subsection{Enzyme Induction by CMC}

Cellulase activity increased with increasing initial concentrations of CMC in medium. (Figure 3 (a) and Figure 3(b), Table 4). The reducing sugar in the medium increased with higher initial concentrations of CMC due to hydrolysis. Up to $2.3 \%$ CMC concentration CMC and FP activity were not inhibited, whereas at a CMC concentration of $4 \%$, the concentration of reducing sugar was $2.3 \%$ and both CMC activity and FPase activity showed a decline. Compared to a catabolite repression/end product inhibition by glucose concentration reported in the case of T.reesei, the results obtained in the current study showed inhibitions at higher concentration of end product. Microcrystalline cellulose (1\%) induced $0.036 \mathrm{IU}$ of FP activity in 72 hrs. whereas, pretreated straw showed 0.034IU of FP activity.

Table 4. Effect of initial concentration of CMC on CMCase and FPase activity

\begin{tabular}{|c|c|c|c|c|c|c|}
\hline \multirow{2}{*}{ CMC \% } & \multicolumn{3}{|c|}{ Undialysed } & \multicolumn{3}{|c|}{ Dialysed } \\
\hline & Sugar \% & CMCase & FPase & Sugar \% & CMCase & FPase \\
\hline 1 & 1.2 & 246 & 92 & 0.3 & 540 & 75 \\
\hline 2 & 1.9 & 356 & 103 & 0.55 & 597 & 125 \\
\hline 3 & 2.3 & 455 & 135 & 0.67 & 769 & 190 \\
\hline 4 & 3.4 & 359 & 162 & 0.8 & 614 & 135 \\
\hline
\end{tabular}

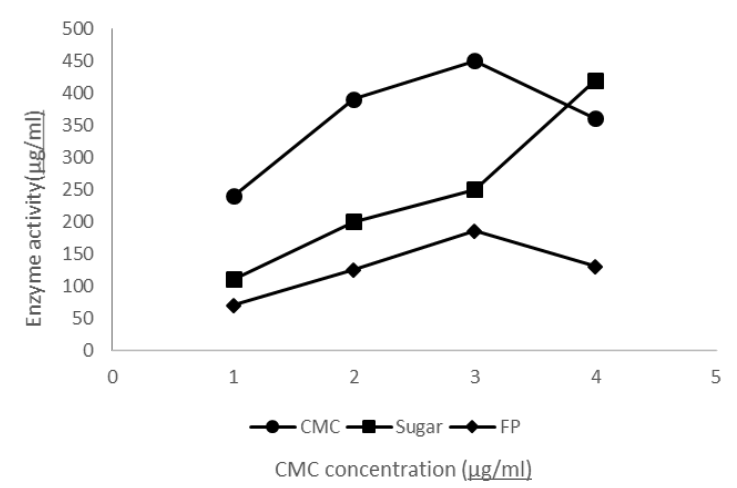

A

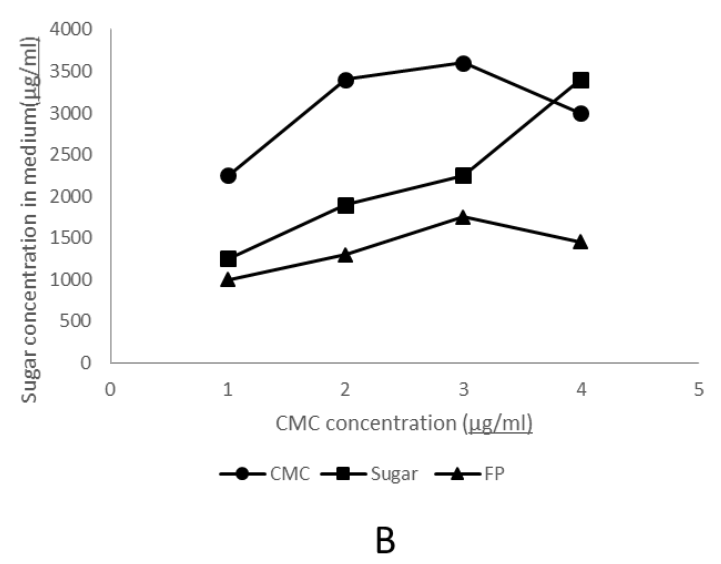

Fig 3. (a) Effect of initial concentration of CMC on CMCase and FPase activity of the isolates, Effect of initial concentration of CMC, on amount of reducing sugar in medium

\subsection{Identification of isolate X1}

Aerial fertile aseptate hyphae producing conidiophores were thick. Vegetative hyphae produced sclerotia. Presence of aseptate conidiophore bearing conidia and foot cells indicate that the fungus is an Aspergillus species. The white hyphal growth with yellow to buff coloured conidiophores, sub globose vesicles, smooth round conidia, pale yellow colour of conidia, secretion of golden yellow fluid, characteristic colour development of black and brown in submerged mycelia, presence of sclerotia and resemblance of aged cultures to that of $A$. terreus indicated that the fungus is Aspergillus flavipes. Morphological observations and the micrometric measurements of the different structures of the isolate are depicted in Table 5.

Table 5. Morphological characteristicsof A. Flavipes

\begin{tabular}{ll}
\hline Morphological characteristics & Dimensions (micro meter) \\
\hline Conidiophore (length) & 400 \\
Conidia (diameter) & 4 \\
Foot cell & 28 \\
Thick hypha (diameter) & 12 \\
Thin hypha (diameter) & 4 \\
\hline
\end{tabular}




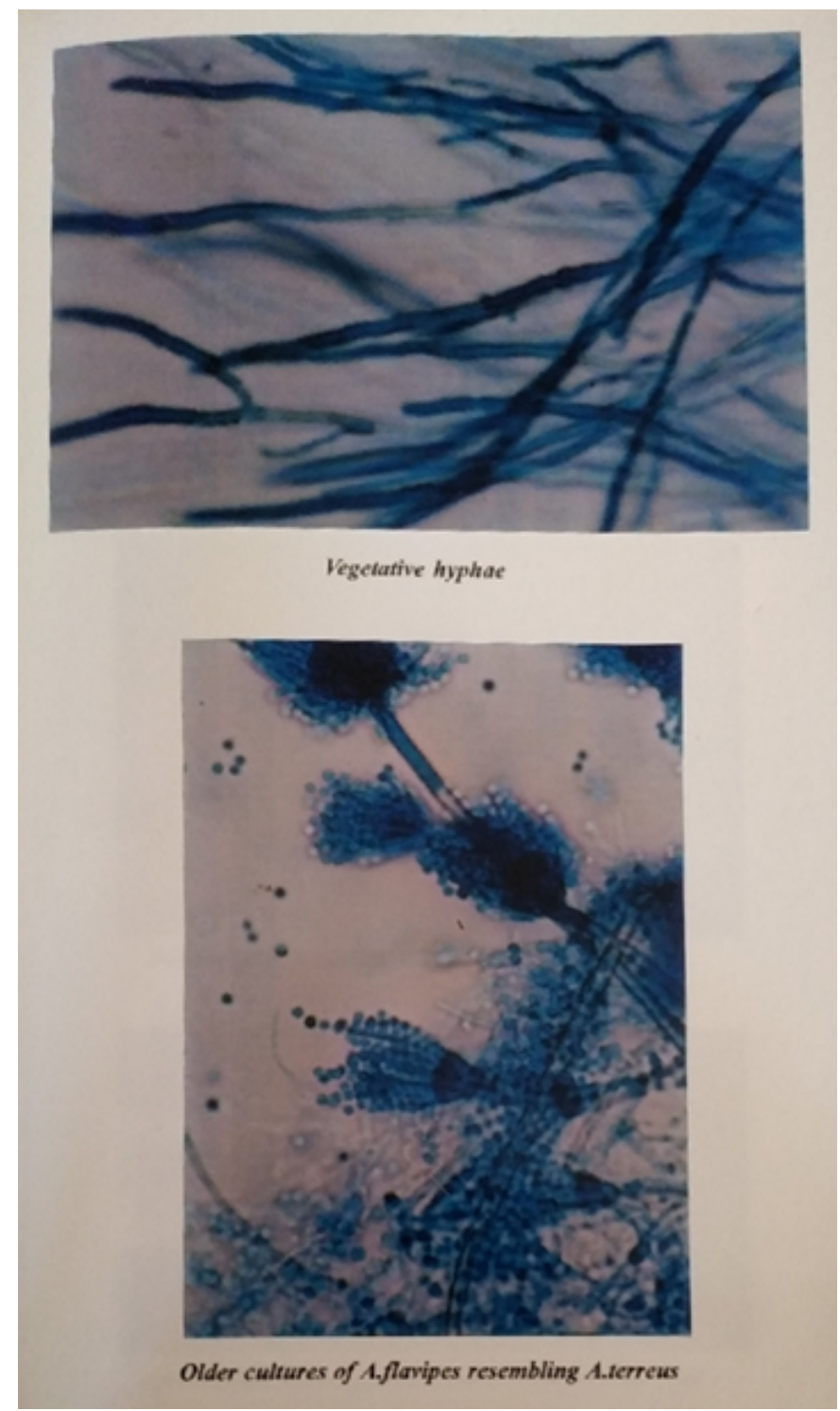

Fig 4. Pictures of the slide culture of the Aspergillus strain

The effect of various factors like temperature $\mathrm{pH}$ and incubation time on the enzymatic activity of the culture supernatant from isolate X1, was studied. It was observed that sugar release and enzyme activity increased progressively up to $72 \mathrm{~h}$, then decreased steadily. Optimal enzyme activity with $\mathrm{FP}$ was observed at a temperature of $60^{\circ} \mathrm{C}$ and a $\mathrm{pH}$ of 5.8. Optimal activity with pNPG and CMC were observed at $50^{\circ}$ Cand $55^{\circ} \mathrm{C}$ respectively. The optimum pH for CMC activity was 5 and with pNPG, it was at pH 5.6. (Data not shown), Enzyme activity of the crude extract with all three substrates FP, CMC and pNPG from the isolate was more stable at $50^{\circ} \mathrm{C}$, than at higher temperatures. The enzyme activity of the crude extract was not significantly affected by a wide range of $\mathrm{pH}$ at $50^{\circ} \mathrm{C}$ (Data not shown).

\section{Purification}

\subsection{Concentration of cellulases}

The activity of crude enzyme with CMC, avicel and pNPG was $2.7 \mathrm{IU}, 1.1 \mathrm{IU}$ and $0.123 \mathrm{IU} / \mathrm{ml}$ respectively. The culture filtrate was concentrated by ultrafiltration resulting in a yield of $14.06 \%$. The total protein, total activity, specific activity and yield with respect to FPase activity are summarized in Table 6. 
Table 6. Summary of the protein purification

\begin{tabular}{|c|c|c|c|c|c|c|}
\hline Enzyme & Step & $\begin{array}{l}\text { Total volume } \\
(\mathrm{ml})\end{array}$ & $\begin{array}{l}\text { Total protein } \\
(\mathrm{mg})\end{array}$ & $\begin{array}{l}\text { Total Activity } \\
\text { ( IU) }\end{array}$ & $\begin{array}{l}\text { Specific activity on specific } \\
\text { substrate IU/mg }\end{array}$ & Yield\% \\
\hline \multirow{3}{*}{ Endoglucanase } & Culture filtrate & 1300 & 1150.5 & 3120 & 2.7 & 100 \\
\hline & Ultra filtrate & 130 & 330.7 & 1061 & 3.2 & 33.9 \\
\hline & Ammonium sulphate & 75 & 96 & 438.2 & 4.5 & 14.06 \\
\hline \multirow{3}{*}{ Avicelase } & Culture filtrate & 1300 & 1150.5 & 459 & 0.4858 & 100 \\
\hline & Ultra filtrate & 130 & 330.7 & 190 & 3.2 & 41 \\
\hline & Ammonium sulphate & 75 & 96 & 133.11 & 3.9 & 29 \\
\hline \multirow{3}{*}{$\beta$-glucosidase } & Culture filtrate & 1300 & 1150.5 & 159.9 & 0.138 & 100 \\
\hline & Ultra filtrate & 130 & 330.7 & 66 & 0.2 & 38.3 \\
\hline & Ammonium sulphate & 75 & 96 & 27.8 & 0.29 & 17.4 \\
\hline
\end{tabular}

\subsection{Ion-exchange chromatography}

Since the majority of cellulases are negatively charged, DEAE Sephadex A-50 was the ion exchange material of choice. Altogether there were 100 fractions of $3 \mathrm{ml}$ each (Table 7, Figure 5). There were seven protein peaks each of which was assayed using the three different substrates. The first enzyme peak was an endoglucanase, exhibiting activity only with CMC. A middle fraction showed activity with both CMC and avicel and the last fraction obtained, showed all the three activities in one peak. This particular peak was purified further by gel permeation chromatography.

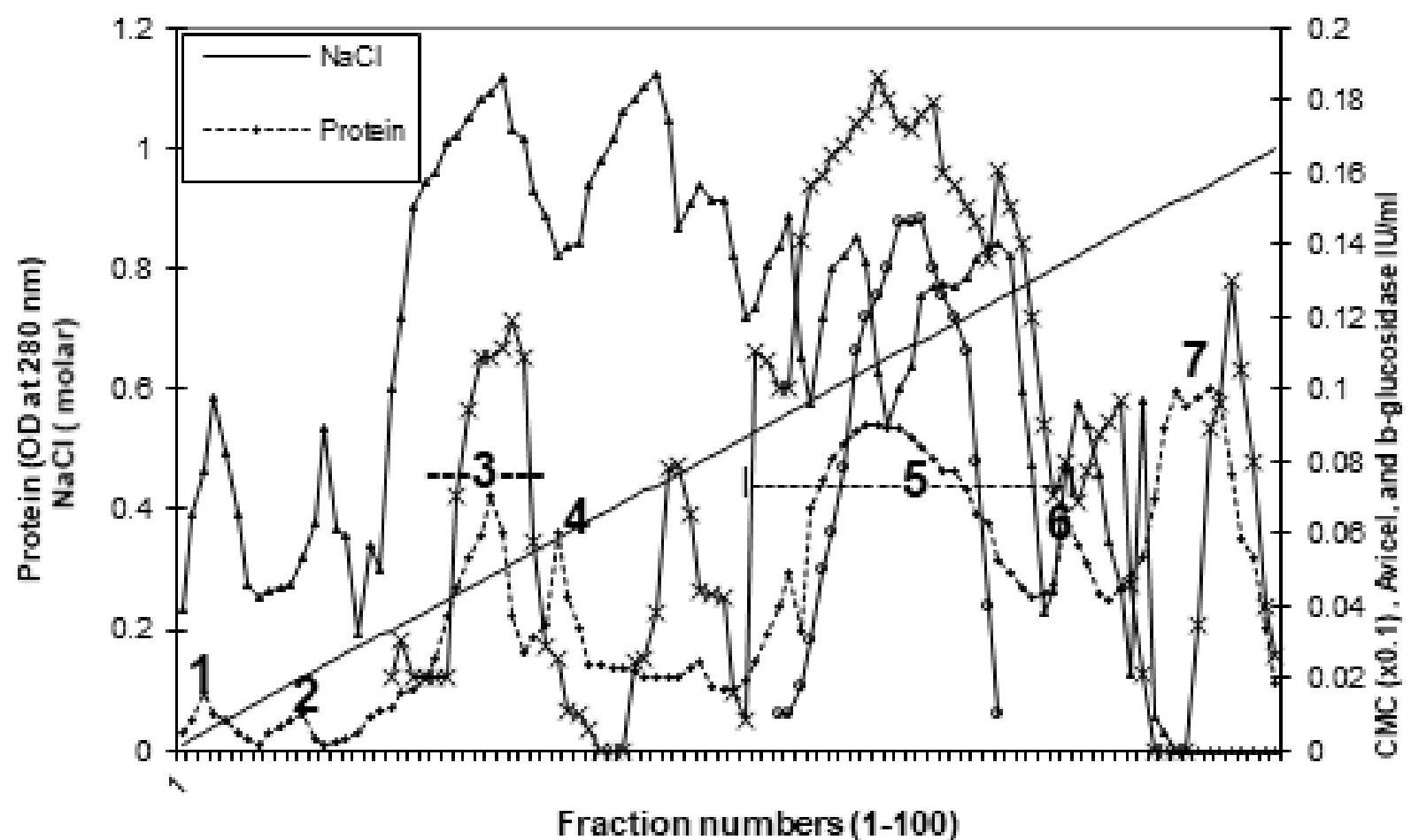

Fig 5. The elution pattern of cellulases with DEAE-Sephadex column chromatography 
Table 7. Cellulase activity of different fractions obtained from ion exchange chromatography

\begin{tabular}{lllllll}
\hline \multirow{2}{*}{ Fractions } & \multirow{2}{*}{ Total volume $(\mathrm{ml})$} & Total protein $(\mathrm{mg})$ & \multicolumn{2}{l}{ Specific activity (IU/mg) on } & Activity ratio CMC /avicel \\
\cline { 4 - 6 } & & & CMC & avicel & pNPG & - \\
\hline $2-9(1)$ & 24 & 1.78 & 2.887 & - & - & - \\
$10-16(2)$ & 21 & 1.152 & 3.48 & - & - & 19.77 \\
$23-34(3)$ & 36 & 15.1 & 1.34 & 0.068 & - & 17.27 \\
$35-40(4)$ & 18 & 6.822 & 1.295 & 0.075 & - & 10.5 \\
$54-79(5)$ & 78 & 18 & 1.77 & 0.169 & - & 4.5 \\
$80-86(6)$ & 21 & 10.8 & 0.44 & 0.098 & - & 1.04 \\
$87-100(7)$ & 42 & 32.4 & 0.054 & 0.05 & - & \\
\hline
\end{tabular}

\subsection{Gel permeation chromatography}

Elution pattern of the ion exchange fraction exhibiting all 3 enzyme activities is depicted in (Figure 6, Table 8). The enzymes were eluted immediately after the void volume. The sample from ion exchange which showed all three activities were resolved into two peaks based on their activity towards the different substrates. First peak showed activity towards both pNPG and avicel eluted at $96 \mathrm{ml}$. It was followed by the second peak which showed both CMC and avicelase activity eluted at $106 \mathrm{ml}$. The molecular weight of the two enzyme samples I and II were 64,000 and 59,000 respectively (Figure 7). The homogeneity of the peaks was tested by doing native PAGE and SDS PAGE.

Table 8. Characteristics of the GPC fractions

\begin{tabular}{lll}
\hline Fraction & Relative elution volume Ve/Vo & Approximate molecular weight \\
\hline 1. Bovine serum albumin & 1.19 & 66,000 \\
2. Carbonic anhydrase & 2 & 29,000 \\
3. Cytochrome C & 2.5 & 12,400 \\
I & 1.2 & 64600 \\
II & 1.35 & 59000 \\
\hline
\end{tabular}

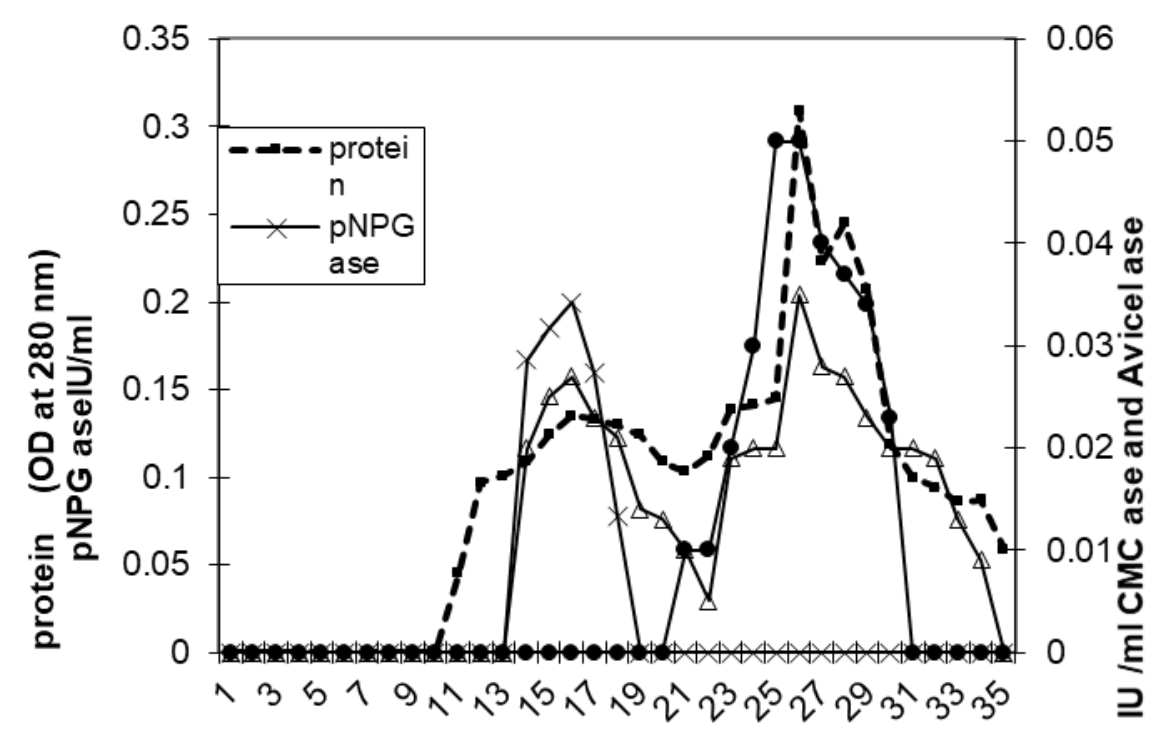

Fraction nos.

Fig 6. Elution pattern ofcellulase fraction in gel permeation chromatography 


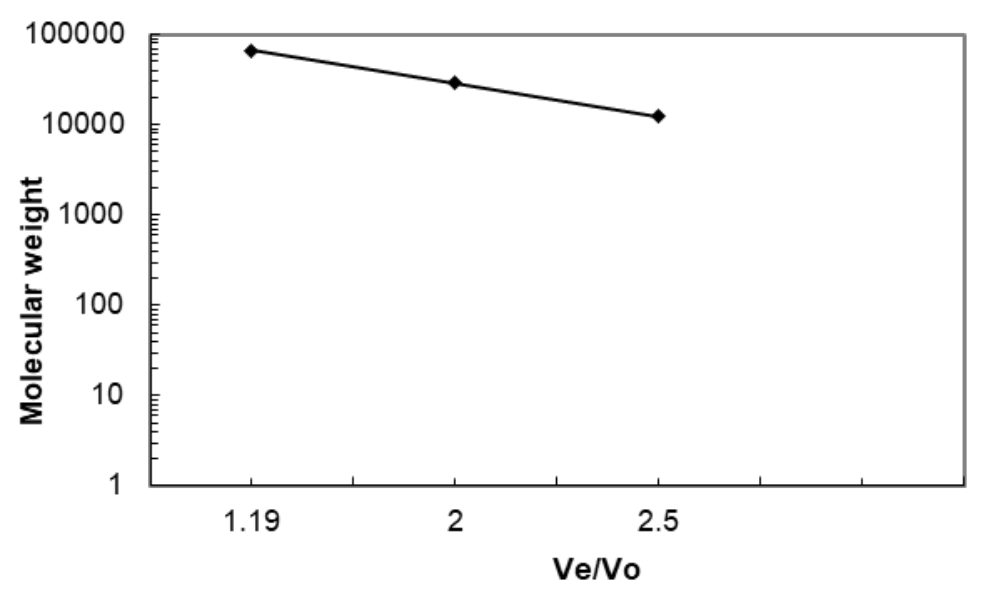

Fig 7. The semi logarithmic plot for determining the molecular weight ofGPC fractions

\subsection{Electrophoresis}

The two peak fractions of GPC were lyophilized and subjected to electrophoresis under non denaturing conditions using acrylamide gels and denaturing conditions using SDS incorporated PAGE. Native PAGE was performed in vertical slab gel system and the homogeneity of the GPC fractions were established by single bands

SDS - PAGE

Based on the Rf values plotted against molecular weights (Figure 8) the molecular weights of the proteins were calculated to be 44,000 and 37,000 which could be monomers of enzymes eluted in the GPC retarded in page due to affinity of glycosylated moiety towards the gel. This can be further confirmed by studying the carbohydrate moieties of the enzyme.

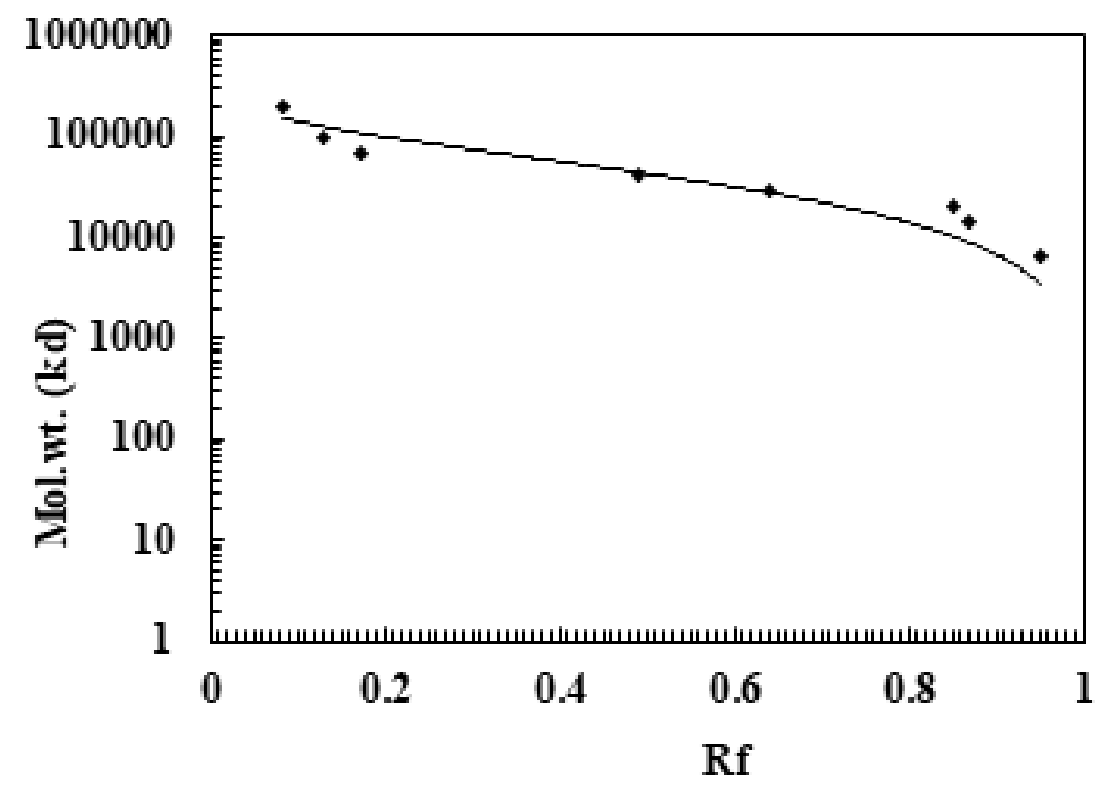

Fig 8. Semilogarithmic graph of molecular weight versus relative mobility 


\section{Discussion}

Cellulase has varied industrial applications and is one of the widely used industrial enzymes. It is instrumental in bioconversion of cellulosic biomass to generate value-added products. e Bio refineries can harness potential of cellulase enzyme as part of the renewable energy ${ }^{(13)}$. The microorganisms that act on the cellulosic biomass can be utilized in the development of sustainable bioprocesses and products ${ }^{(14,15)}$. The search for novel systems to be used independently or in synergy with cellulases from other sources in order to enhance the efficiency as well as to reduce the cost of production are highly relevant. Cellulase production in high amounts with native substrates without extensive pretreatment is possible when xylanases or laccases are produced by the organism which performs simultaneous saccharification and fermentation to bring down the cost ${ }^{(16,17)}$. The microorganisms and their cellulase production profiles is highly dependent on factors like differences in fermentation conditions, media composition, and raw materials employed for cellulase production. Hence comparison of recalcitrant microcrystalline cellulose bioconversion (\% conversion/h) using crude enzymes of different strains requires use of optimum culture conditions. Aspergillus species are filamentous fungi known to produce cellulolytic enzymes in high titres ${ }^{(18)}$. While -glucosidase activity is higher and endoglucanse level is lower in the cellulases obtained from Aspergillus, Trichoderma shows lower -glucosidase activity and higher endo and exoglucanase components. The strain isolated in our lab would be suitable for lignocellulosic biomass as it produced considerable amount of cellulase even in the presence of native cellulose ${ }^{(19)}$. The optimum $\mathrm{pH}$, and temperature of this strain also would enable its utilization in conjunction with other enzymes to form cocktails. The enzymes are relatively thermostable, stable over longer periods over a wide range of $\mathrm{pH}$ at $50^{\circ} \mathrm{C}$ and relatively resistant to catabolite repression. In this study, the FP activity was found to be more thermostable than endoglucanase activity contrary to reported cases of $T$ reesei cellulases, hence this enzyme complex could be paired with $T$ reesei cellulases for commercial applications resulting in a highly effective cocktail of enzymes. Moreover, this the strain exhibits maximal enzyme production at shorter fermentation times rendering it more productive than other cellulase producing strains.

The quantitative analysis of the single enzymes cannot be determined if the activity measurements involve substrates like filter paper, Avicel and carboxymethylcellulose. Crude culture filtrates of Trichoderma culture results in overlapping peaks and co elution of several proteins in the chromatograms. Along with the cellulases and isoforms, the presence of hemicellulases, amylases, proteases and other proteins were reported. This would not be resolved with a single chromatographic run. In ion exchange one enzyme might occur in two conformations at two different $\mathrm{pH}$ and bind differently to column eluting in two peaks electrophoretically. Pure enzyme from $T$. reesei was eluted in two peaks as they exist in two conformations at two $\mathrm{pH}$ and bind differently. Resolution of isoforms of enzyme differing in glycosylations are sometimes not achieved ${ }^{(20)}$. The ion exchange fractions were majorly three. Fraction I is a typical endoglucanase, fraction II exhibited activity towards both avicel and CMC. The Fraction III which exhibited all the three activities were subjected to GPC. We were able to obtain two peaks which showed atypical activity. Fraction I had activity against both avicel and pNPG. Fraction II showed activity against CMC and avicel. These enzymes gave only single bands in SDS PAGE which established the purity of fractions. Hence, it can be concluded that these enzymes show cross reactivity to substrates used.

$\beta$-Glucosidase is a part of the saccharification of cellulose as it converts cellobiose to glucose. It combines with the endoglucanase and cellobio-hydrolase for cellulose degradation, thereby proving its significance in the cellulase enzyme system. $\beta$-Glucosidase from T. harzianum type C-4 was purified to homogeneity through Sephacryl S-300, DEAE-Sephadex A-50, and Mono P column chromatography. It was reported to be a single polypeptide with the molecular mass of 75,000 by SDS-PAGE. The activities showed similarities to both aryl glycoside and oligosaccharides ${ }^{(21)}$. According to Enari et al, there are three types of $\beta$ - glucosidases based on their substrate specificities ${ }^{(22)}$. Based on these reports, it can be inferred that that the fraction obtained during chromatography in our study, which had both avicelase and $\beta$-glucosidase activity, could be a member of the third group of beta glucosidase possessing hydrolytic activity towards oligosaccharides.

According to Hoshino et al., the action of both endo and exo enzymes on cotton after microscopic observations of effect of highly purified enzymes on cotton ${ }^{(23)}$. A study reported that an endoglucanase, showing typical endoactivity resulting in release of cellobiose, cellotriose and glucose from $\mathrm{H} 3 \mathrm{PO} 4$ swollen cellulose also showed high specific activity with avicel ${ }^{(24)}$. Another study reported purification of an endocellulase from culture supernatant of a new isolate Streptomyces sp. $L X$, was obtained and purified to homogeneity, it is called endocellulase ${ }^{(25)}$. It is also known as endoglucanase and exhibited both endo- and exocellulase activities. An enzyme purified from Aspergillus aculeatus, was identified as endoglucanase, and showed high specific activity toward CM-cellulose and low specific activity towards avicel ${ }^{(26)}$. These were found to reside on a monomeric protein of $48 \mathrm{kDa}$. From these previous studies, it was clear that the second fraction in our work is a glucosidase with oligosaccharide hydrolytic properties. In the present study an endoclucanase (with and without atypical activity) and a potent glucosidase, which could use avicel as substrate were purified. These enzymes together constitute a novel enzyme system for saccharification of cellulose. Moreover, this organism could reduce the cost of production of cellulases due to higher titres in shorter fermentation duration and as it produces xylanases along with cellulases, cheaper lignocellulosic material without much pretreatment could 
be used as raw material.

\section{Conclusion}

Possession of cellulases and xylanases acting on a wide range of substrates, render the isolate a potential candidate for utilizing native cellulosic substrates. Cellulolytic activity of the fungus A. flavipes higher than the other strains isolated and tested in this study as well as cellulolytic activity of standard strain T. koninjii. To the best of our knowledge this is the first report of production and purification studies of a cellulolytic enzyme system from Aspergillus flavipes. The thermostability at a wide range of $\mathrm{pH}$ at $50^{\circ} \mathrm{C}$ makes it suitable for biotechnological processes at temperatures of this range. Different types of endoglucanases, and beta glucanases which could act on crystalline cellulose and avicel were purified and this novel system of cellulases could be suitable for processes like industrial lignocellulosic saccharification and bioconversion to fuels both independently or in combination with other enzymes.

\section{Acknowledgement}

The first author is indebted to the CSIR, India for providing financial assistance for the study in the form of research fellowship.

\section{References}

1) Chandel AK, Chandrasekhar G, Silva MB, da Silva SS. The realm of cellulases in biorefinery development. Critical Reviews in Biotechnology. 2012;32(3):187-202. Available from: https://dx.doi.org/10.3109/07388551.2011.595385.

2) Fan LT, Gharpuray MM, Lee YH. Cellulose Hydrolysis;vol. 3 of Biotechnology Monographs. and others, editor;Springer-Verlag Berlin Heidelberg. Springer Science \& Business Media. 1987. doi:10.1007/978-3-642-72575-3.

3) Jalak J, Kurašin M, Teugjas H, Väljamäe P. Endo-exo Synergism in Cellulose Hydrolysis Revisited. Journal of Biological Chemistry. 2012;287(34):2880228815. Available from: https://dx.doi.org/10.1074/jbc.m112.381624.

4) Ariffin H, Abdullah N, Kalsom MU, Shirai Y, Hassan Y. Production and characterization of cellulase by Bacillus pumilus EB3. Int J Eng Technol. 2006;3(1):47-53.

5) Juturu V, Wu JC. Microbial cellulases: Engineering, production and applications. Renewable and Sustainable Energy Reviews. 2014;33:188-203. Available from: https://dx.doi.org/10.1016/j.rser.2014.01.077.

6) Sukumaran RK, Singhania RR, Pandey A. Microbial cellulases - Production, applications and challenges. Journal of Scientific and Industrial Research. 2005;64(11):832-844. Available from: http://hdl.handle.net/123456789/5375.

7) Sharrock KR. Cellulase assay methods: a review. Journal of Biochemical and Biophysical Methods. 1988;17(2):81-105. Available from: https://dx.doi.org/ $10.1016 / 0165-022 x(88) 90040-1$.

8) Ghose TK. Measurement of cellulase activities. Pure and Applied Chemistry. 1987;59(2):257-268. Available from: https://dx.doi.org/10.1351/ pac198759020257.

9) Wood TM, Bhat KM. Methods for measuring cellulase activities. Methods in enzymology. 1988;160:87-112. Available from: https://doi.org/10.1016/00766879(88)60109-1.

10) Mandels M, Weber J, Parizek R. Enhanced cellulase production by a mutant of Trichoderma viride. Applied microbiology. 1971;21(1):152.

11) Onions A, Allsopp D, Eggins H. Smith's introduction to Industrial Mycology. Edward Arnold, London. 1981.

12) Domsch KH, Gams W, Anderson TH. Compendium of soil fungi;vol. 1. and others, editor;London. Academic Press Ltd. 1980.

13) Champreda V, Mhuantong W, Lekakarn H, Bunterngsook B, Kanokratana P, Zhao XQ, et al. Designing cellulolytic enzyme systems for biorefinery: From nature to application. Journal of Bioscience and Bioengineering. 2019;128(6):637-654. Available from: https://dx.doi.org/10.1016/j.jbiosc.2019.05.007.

14) Kuhad RC, Gupta R, Singh A. Microbial cellulases and their industrial applications. Enzyme research. 2011;p. 1-10. Available from: https://doi.org/10. $4061 / 2011 / 280696$

15) Sadhu S, Maiti TK. Cellulase production by bacteria: a review. British Microbiology Research Journal. 2013;3(3):235-258. Available from: https: //doi.org/10.9734/BMRJ/2013/2367.

16) Zhang XZ, Zhang YHP. Cellulases: Characteristics, Sources, Production, and Applications. In: Yang ST, El-Enshasy HA, Thongchul N, et al., editors. Bioprocessing Technologies in Biorefinery for Sustainable Production of Fuels, Chemicals, and Polymers. Oxford University Press (OUP). 2014. Available from: https://doi.org/10.1002/9781118642047.ch8. doi:10.1093/rb/rbu004.

17) Pinar O, Karaosmanoğlu K, Sayar NA, Kula C, Kazan D, Sayar AA. Assessment of hazelnut husk as a lignocellulosic feedstock for the production of fermentable sugars and lignocellulolytic enzymes. 3 Biotech. 2017;7(6):367. Available from: https://doi.org/10.1007/s13205-017-1002-4.

18) Milala M, Shugaba A, Gidado A, Ene A, Wafar J. Studies on the use of agricultural wastes for cellulase enzyme production by Aspergillus niger. Research journal of agriculture and biological sciences. 2005;1(4):325-333.

19) Bronnenmeier K, Kern A, Liebl W, Staudenbauer WL. Purification of Thermotoga maritima enzymes for the degradation of cellulosic materials. Applied and environmental microbiology. 1995;61(4):1399-1407. Available from: https://dx.doi.org/10.1128/aem.61.4.1399-1407.1995.

20) Medve J, Lee D, Tjerneld F. Ion-exchange chromatographic purification and quantitative analysis of Trichoderma reesei cellulases cellobiohydrolase I, II and endoglucanase II by fast protein liquid chromatography. Journal of Chromatography A. 1998;808(1-2):153-165. Available from: https: //dx.doi.org/10.1016/s0021-9673(98)00132-0.

21) Yun SI, Jeong CS, D-K C, Choi HS. Purification and some properties of a $\beta$-glucosidase from Trichoderma harzianum type C-4. Bioscience, biotechnology, and biochemistry. 2001;65(9):2028-2060. Available from: https://doi.org/10.1271/bbb.65.2028.

22) Enari TM, Niku-paavola ML. Enzymatic Hydrolysis of Cellulose: is the Current Theory of the Mechanisms of Hydrolysis Valid? Critical Reviews in Biotechnology. 1987;5(1):67-87. Available from: https://dx.doi.org/10.3109/07388558709044153. 
23) Hoshino E, Sasaki Y, Mori K, Okazaki M, kazutosi Nisizawa, Kanda T. Electron Microscopic Observation of Cotton Cellulose Degradation by Exo- and Endo-Type Cellulases from Irpex lacteus. The Journal of Biochemistry. 1993;114(2):236-245. Available from: https://dx.doi.org/10.1093/oxfordjournals. jbchem.a124160.

24) Kim DW, Jeong YK, Jang YH, Lee JK. Purification and characterization of endoglucanase and exoglucanase components from Trichoderma viride. Journal of fermentation and bioengineering. 1994;77(4):363-369. Available from: https://doi.org/10.1016/0922-338X(94)90005-1.

25) Li X, Lin W, Gao P, Chen F. Endoglucanase S, a novel endocellulase exhibiting exoglucanase activity from a newly isolated Streptomyces sp. LX. Journal of Applied Microbiology. 1998;85(2):347-356. Available from: https://dx.doi.org/10.1046/j.1365-2672.1998.00518.x.

26) Naika GS, Kaul P, Prakash V. Purification and Characterization of a New Endoglucanase fromAspergillus aculeatus. Journal of Agricultural and Food Chemistry. 2007;55(18):7566-7572. Available from: https://dx.doi.org/10.1021/jf070710p. 